\section{MEDICAL STUDIES IN BRITAIN}

$\mathrm{F}^{\mathrm{H}}$ OM time to time the British Medical Bulletin - publishes articles by experts on the development of medical studies in Britain. The first of these, on the development of ophthalmology (Brit. Med. Bull., 1,100 ; 1943), was noticed in Nature $(153,383$, March 25, 1944). The second, third and fourth have now appeared (Brit. Med. Bull., 2, Nos. 5-6 ; 1944). The second is on the genetic aspect of disease, by Dr. Julia Bell ; the third is on obstetrics, by Prof. James Young, of the British Postgraduate Medical School, London; the fourth is on oto-laryngology, by Dr. Douglas Guthrie.

Dr. Bell, beginning with a quotation from Hippocrates (400 B.c.) on the hereditary origin of epilepsy, briefly outlines the subsequent history of ideas on the hereditary nature of some diseases. What she tells us of Karl Pearson is interesting because she was his assistant during 1908-14. Her discussion of modern genetics is a valuable summary in the short space available of a complex subject. Fundamental features of this third period of her survey have been the conception of the gene and its localization in the chromosome, and the study of linkage. Work of this kind has, she says, a limited application to hereditary disease in man, but notable work has been done on colour blindness and hæmophilia. The work on blood groups has been among the most important of the single discoveries made. Dr. G. L. Taylor, Dr. R. R. Race and Dr. W. T. J. Morgan have explained this work in an issue of the journal which is devoted to the blood and some of its disorders (Brit. Med. Bull., 2 , Nos. $8-9$; 1944). The collection of the pedigrees of disease continues, says Dr. Bell, and there can be few in Great Britain who are better qualified than she is to discuss this method of investigation. She also discusses genetic work on cancer and leukæmia. If it is not possible, she says, to stay the onset or course of disease or of a defect which is genetically determined, preventive measures, such as the discouragement of consanguineous marriages or voluntary sterilization of possible transmitters of such diseases, have been considered. Dr. Bell concludes that little is to be expected from the former method, and that the latter may be very wasteful. There is, she thinks, great promise in the work now being done in experimental genetics and embryology, but the results obtained by the study of relatively primitive organisms should be applied to the human species with caution. The selected bibliography which she gives is valuable.

Prof. James Young traces British midwifery back to the reign of Henry VIII, when, in 1540, the first British text-book on the subject appeared-a translation of Rösslin's book published in Hagenau in 1513. Little progress was made during the sixteenth and seventeenth centuries, when practitioners of midwifery were mostly the ignorant and illiterate midwives who called in the doctor "with his destructive instruments" in emergencies. But Paré, in France in 1550, discovered the value of podalic version, and from this Prof. Young dates the rise of modern obstetrics. Obstetric forceps, "one of the greatest and most beneficent of all obstetric discoveries", were invented about $1630-34$, but they remained a close secret of the English Chamberlen family for more than a century. Their use did not become general until Chapman first described them in 1713. It was William Harvey who introduced a new intellectual spirit into the study of obstetrics, but he strangely failed to realize the truth taught by his teacher Fabricius that the child is born by the muscular action of the womb, insisting that it "attacks the portals of the womb" and gets out by its own efforts. Harvey and others, including the Chamberlen family, made improvements in the status and instruction of midwives, and some control of them was instituted.

Harvey and his friends emphasized that labour was a natural physiological process and did not favour interference until it was clear that it was necessary; and this idea dominated the British school of obstetrics throughout the eighteenth century. By the middle of this century the British school had made such progress that it led the world. The genius of William Smellie (1697-1763) earned for him the description as. "one of the most important obstetricians of all times and all countries". Prof. Young gives an interesting description of the fight between the men and women midwives. It is only recently that the British midwife has been given by the Midwives Act of 1902 and subsequent legislation "a position of prime importance in the maternity organization of the country". With the nineteenth century came anæsthesia, antiseptic and later aseptic surgery, and the story of the control of puerperal sepsis, the contagious nature of which was suspected by Gordon in Aberdeen in 1795 and independently in 1843 by Oliver Wendell Holmes in America and by Semmel. weiss in Vienna. The fact that a streptococcus was the cause was demonstrated by Pasteur in 1867 . British bacteriologists have played a notable part in the prevention of obstetric contagion.

The rest of this interesting article deals with the history and present position of preventive aspects of obstetrics and with the recognition of obstetrics as a special branch of medicine. "Gynæcology," says Prof. Young, "is a creation of the nineteenth century." It dates from the work of Virchow and the creation of the microscope. In the same issue of the British Medical Bulletin, Dr. W. C. W. Nixon writes on nutrition and pregnancy and lactation, and there are valuable reviews of selected papers on subjects of obstetrical and gynæcological interest.

Dr. Douglas Guthrie's article on oto-laryngology takes us back to Fallopius, whose name is familiar to every first-year student of biology. Fallopius wrote in 1564 what was probably the first complete book on the ear. It was not until 1748 that Duverney, of Paris, demonstrated that the Eustachian tube was not a means of breathing or hearing, but simply a means of renewing the air in the tympanum. Willis, of Oxford, also known to students of biology and medicine as the discoverer of the 'circle of Willis' and other features of the nervous system, published in 1683 his treatise entitled "Two Discourses concerning the Soul of Brutes", in which he gave an account of the phenomenon of hearing better in a noise (paracusis Willisi) and told of a woman who, though she was deaf, could hear every word perfectly so long as a drum was beaten in her room; her husband kept a drummer so that he could talk to her.

During the eighteenth century two of the most important instruments used in oto-laryngology were invented, both by laymen. Guyot, a postmaster of Versailles, produced in 1724 a form of the Eustachian catheter, which he introduced through his own mouth in order to syringe his ear and so relieve his deafness. In 1854 the Parisian singing master and singer, Manuel Garcia, invented the laryngoscope in order to see the action of his own vocal chords. But 
in the eighteenth century oto-laryngology was chiefly concerned with diphtheria, which was very prevalent and fatal then. The first hospital in the world to be devoted to diseases of the ear, the Royal Ear Hospital, was founded in 1816 by J. H. Curtis, an unqualified man who had a large practice in London. The subsequent history of oto-laryngology brings us to Joseph Toynbee (1815-60), the father of Arnold Toynbe日, James Hinton (1822-75), also remembered as a philosopher, and Sir William Wilde, of Dublin (1815-76), the father of Oscar Wilde. Toynbee's beautiful dissections were preserved in the Museum of the Royal College of Surgeons until they were destroyed by enemy action in 1941.

Laryngology became a special branch of medicine in the middle of the nineteenth century and Sir Morell Mackenzie was the founder of modern laryngology. Another great laryngologist was Sir Felix Semon, a German pupil of Mackenzie's who settled in London. Semon was one of the last to practise laryngology before it became merged with otology. Nowadays developments in bronchoscopy and oesophagoscopy are extending the boundaries of the science of oto-laryngology; and speech and voice disorders offer a further field.

Dr. C. S. Hallpike, in another article in this issue of the British Medical Bulletin, discusses research in otology and Dr. E. H. Broome discusses the scope of speech therapy. Dr. Guthrie provides a second article, on "Pioneers in the Teaching of the Deaf". A discussion on the audibility of the radio voice at a meeting of the Royal Society of Medicine will interest lay readers who are habitual radio listeners. It is evident that the radio speaker has to deal with a complex problem. Mr. John Snagge said in this discussion that it is impossible to tell from gramophone records whether a speaker will be a success at the microphone, and also that the construction or lining of the walls of a room in which a broadcaster speaks has little effect on the reception of his voice by the distant listener. The quality of the voice is often more important than the speed of the speech.

Peripheral vascular disorders are the subject of a valuable article by Prof. J. R. Learmonth (Brit. Med. Bull., 2, No. 7 ; 1944). This issue is devoted to the peripheral blood vessels and deals with arterial spasm, arterial injuries and injuries due to low temperature, such as frostbite. Fifteen photographs illustrate the article on the pathology of immersion foot. The study of these conditions is always an important one, but it is perhaps even more important in these times of war and air-raid casualties. G. LAPAGE.

\section{DECIDUOUS CYPRESS (Taxodium distichum) BY ALEXANDER L. HOWARD}

$\mathrm{T}$ HIS beautiful tree, the only cypress which sheds its leaves in the winter, is far too little known and appreciated by those who possess it. In spring its light-coloured feathery leaves fall gracefully from the pyramidal shape of the tree; in summer the full effect of the foliage is different from anything else in the landscape; in autumn it reaches perfection, when the sprays turn a golden hue, almost reminiscent of a set piece in a firework display; and in winter its curious habit of growth attracts the eye, because of its weird, almost ghostly appearance.
It is known in the United States by the names of bald cypress, swamp cypress and Louisiana cypress, and according to Sargent "rarely 12 feet and generally 4-5 feet in diameter above the abruptly enlarged strongly buttressed usually hollow base", occasionally $150 \mathrm{ft}$. high, but in Great Britain the maximum height and girth recorded is $110 \mathrm{ft}$. by more than $12 \mathrm{ft}$.

It is to be found sparsely distributed over a wide area, generally by the banks of streams, rivers or lakes. While it can be reared apart from such positions, it is essentially a tree dependent upon water-ways. Introduced from other countries, it has both suffered and benefited by the fashion of the day. For the last half-century it has been almost forgotten, while in the beginning of the nineteenth century it was extensively planted, and a number of these trees are still flourishing to-day, but inquiries I have made seem to show that few, or perhaps scarcely any, have been planted during the last halfcentury. Interesting accounts of many fine examples are catalogued by Elwes. He mentions :

"The trees at Syon Thave been frequently described and figured. They are planted in damp soil by the side of a sheet of water, and one of them has produced knees of 1 to 2 feet high. This tree ... measured in 1903 90 feet by 12, but there is a much taller one on the other side of the water, which when we saw it last, in 1905, was $110 \mathrm{ft}$. high, and is the tallest we know of in Europe. Another, in the Duke's Walk, is 85 feet by 10 feet 3 inches."

In October 1944 I visited Syon and the trees were in perfect health. I was doubtful which one Elwes found to be $90 \mathrm{ft}$. by $12 \mathrm{ft}$., but I measured the largest, which exactly answered his description of site, and found it to be $21 \mathrm{ft}$. around the base. The knees rising to $2 \mathrm{ft}$. and a little more range around the tree on three sides-on the south side to $52 \mathrm{ft}$., on the west side to $46 \mathrm{ft}$., and on the north side to more than $40 \mathrm{ft}$. There is also on the other side of the walk a very handsome young tree about 80 $90 \mathrm{ft}$. high and $12 \mathrm{ft}$. girth at the base.

\section{Elwes also reports:}

"At White Knights, Reading, there are several trees, but none of large size, the biggest measuring, in 1904, 67 feet by $7 \mathrm{ft}$. 10 inches. They are remarkable, however, for variety of habit. One is a tall narrow tree with upright branches, almost fastigiate. In another tree the stem is twisted, as often occurs in the chestnut, and most of the branches are twisted also in the direction against the sun. Loudon mentions these as young trees of peculiar habits."

Mr. F. G. Franklin, at White Knights, writes to me under date of October 7, 1944, as follows: "the trees you mention are still alive but I could not say they are very much larger than you say."

\section{And further :}

"At Strathfieldsaye there is a tree, mentioned by Loudon as being 46 feet in height by $3 \mathrm{ft} .4$ in. in dia. meter, which I found in 1903 to be $63 \mathrm{ft}$. high by $9 \mathrm{ft}$. in girth ( $I$ have a letter from the Duke of Wellington in October 1944, in which he informs me this is now $69 \mathrm{ft}$. and the girth $11 \mathrm{ft} .6 \mathrm{in}$. at $5 \mathrm{ft}$.) It is growing in stiff clay soil and has no knees : the stem is deeply furrowed.

"At Coombe Abbey, Warwickshire, Mr. W. Miller reports that a tree, mentioned by Loudon as $47 \mathrm{ft}$. by $2 \mathrm{ft} .3$ in. (diameter e.d.) in 1843 , had attained, in 1887 , $75 \mathrm{ft}$. by $11 \mathrm{ft} .6 \mathrm{in}$. at $3 \mathrm{ft}$. from the ground. [In answer to an inquiry I am told by Mr. J. G. Gray there has been no such tree there for the past 22 years.]

"At Brockett's Park, near Hatfield, there are many trees planted along a walk on the banks of the Lee, and 